\title{
The Early Literary Reception of Ernest Hemingway in Iran
}

\author{
Atefeh Ghasemnejad*, Alireza Anushiravani \\ Department of Foreign Languages \& Linguistics, Shiraz University, \\ Corresponding Author: Atefeh Ghasemnejad, E-mail: atefeh.ghasemnejad@gmail.com
}

\section{ARTICLE INFO}

Article history

Received: December 10, 2017

Accepted: January 13, 2018

Published: January 31, 2018

Volume: 6 Issue: 1

Conflicts of interest: None

Funding: None

\begin{abstract}
This essay investigates the dynamics that led to the literary reception of Ernest Hemingway before the Islamic Revolution in Iran. This article deploys reception studies as a branch of Comparative Literature with a focus upon conceptions of Siegbert Salomon Prawer and the practical method of George Asselineau to unearth the ideological, political, and historical milieu that embraced Hemingway's literary fortune in Iran. This investigation, unprecedented in the study of Iranian literature, discusses how and why Hemingway was initially received in Iran. As such, the inception of literary fortune of Ernest Hemingway in Iran is examined by the contextual features, Persian literary taste, and the translator's incentives that paved the way for this reception. This article also uncovers the reasons for the delay in the literary reception of Hemingway in Iran and discussed why some of Hemingway's oeuvres enjoyed recognition while others were neglected by the Iranian readership.
\end{abstract}

Key words:

Culture in transition,

Policy of simplification and purification,

Ideology of translator,

Ebrahim Golestan, Sa'di Shirazi,

Najaf Daryabandari

\section{INTRODUCTION}

Reception of a literary figure in a country other than the writer's home country is crucial to the overall literary enquiry of that country. It is a fresh way of seeing a given literature through the lens of external and international literature. Investigation of literary fortune of a writer in a country other than his/her own is one of the popular and enlightening fields of research. Although reception studies within the general framework of comparative literature is popular in other countries, such studies are not embraced as serious and illuminating fields of research by Persian scholars. Indeed, comparative literature was introduced to Iran in 1940s by Fatemeh Sayah whose thesis dissertation was on Anatole France. Her untimely death in 1947 left this burgeoning project unfinished (Anushiravani, "Nesbate" 52). As Anushiravani (2015) notes, "although Abol Hasan Najafi, Abdol Hossein Zarinkub, Khosro Farshidvard, Hasan Honarmandi, and Hasan Javadi followed this sensible lady [Fatemeh Sayah], they did not succeed" as her true disciples since "they did not adhere to the theoretical framework, nor did they define the scope of research in their studies" ("Nesbate" 52).
In fact, inspections into the literary reception of an author opens perspectives to the works and the social and cultural milieu in which they are presented. Siegbert Salomon Prawer sets George Asselineau's article, titled "French Reactions to Hemingway's Works between the two World Wars" as a practical example of a successful investigation into the literary reception of a writer. George Asselineau deploys a chronological study of the translations and criticisms of Hemingway's works in France in order to uncover the contextual features that led to the reception of Hemingway's works in two decades. As such, he investigates into the literary taste of French people, the status and fame of the translator and the translation industry in France.

In order to find out the literary fortune of Hemingway in Iran, this study deploys George Asselineau's methodology to inquire Hemingway's literary reception in Iran. Due to the unprecedented nature of these investigations in Iran, the application of reception theory in the light of Comparative studies can serve as an instigator and propagator of this rich field of enquiry in Iranian scholarship. This study investigates the early reception of Hemingway's fame in Iran, span- 
ning from 1949 to 1978 , and the reasons for his reception. It also argues why and how Hemingway is assimilated within Iranian culture.

\section{THE CONCEPTION OF LITERARY RECEPTION}

Reception studies, as Robert C. Holub (1984) marks, is not subject to studies in Reader Response Theory and ideas that flourished in the Constance School, "the critical movement ... [that is] associated with the University of Constance" (xiii). François Jost (1975) classifies reception studies as a subcategory of influence study. For him, influence studies is comprised of "source", "fortune or reception studies," "image or mirage" and "the relationship between literature and other disciplines" (Jost 21-67). Fortune studies, is "the response or the success or the impact that the literature of one country attains in the literature of another" (Jost 34). Source includes "the inspiration or information supplied or nourished by foreign authors or books" (Jost 34). Although Jost deploys the term reception studies in relation with influence studies, he allows the comparatist to focus on the "receiver" rather than the "source" suggesting that the analyst can be "concerned with the result or degree of absorption" rather than the "how of transmission" (Jost 34).

Among various theorists and scholars of comparative studies, Siegbert Salomon Prawer's elaboration of reception studies is prominent in practice. Prawer (1973) does not limit the scope of reception studies to influence studies. He believes that the rules for reception studies are already defined and new scholars can rely on the experience of the past (Prawer 26). Prawer sets a pragmatic example of reception study with a delineation of Roger Asselineau's article on Hemingway's reception in France. As Prawer notes, Asselineau examines 'the chronology of French translations of Hemingway's work' and "the articles and reviews" (32). Additionally, Prawer argues that besides a quick glimpse at the ups and downs of Hemingway's fortune in France, Asselineau also singles out the periods of "French interest" in Hemingway (32). Prawer's sample of Asselineau's investigation can serve as a good model for reception studies of Ernest Hemingway in Iran since Roger Asselineau's analysis has vigour and profundity of fashion as his chief purpose is to examine "the overall impact of Hemingway's works during the two decades' (39) rather than studying the French reader's 'inchoate reactions [that] would amount to dissecting buds in order to discover characteristics which are obvious in the full-grown plant" (39).

\section{LITERATURE AND SOCIAL REALITIES: A CONTEXTUAL STUDY}

Understanding the literary fortune of Ernest Hemingway in Iran is not possible without the knowledge of Iranian literary taste, social, ideological, and historical background. In this respect, it is necessary to review the historical conflict between modernity and tradition given the political and social and literary spheres. Modern Persian literature and culture have been influenced by the civil political disturbances and revolutions such as the constitutional revolution from 1905 to 1911 , Islamic Republic Revolution in 1979, and the eightyear war against Iraq from 1980 to 1988.

These political and social changes in different historical periods are responsible for varying ideological formation of each episode in literary movements. Kamran Talattof (2000) asserts that Persian literature is "highly ideological in [its]... representation" (1). He marks that in comparison to other literatures, "the impact of ideology on the formation of modern Persian literature is more complex [because] Persian literary history is not an integrated continuum but a series of distinct episodes distinguishable by their ideology of representation" (3). Modern Persian literature was instigated in the early twentieth century after the Constitutional Revolution (Mirsadeghi 15). It is characterized by simplicity of style as opposed to the ornate traditional style prevalent during Qajar period that was ornamented with circumlocution and unfamiliar Arabic words. Indeed, simplification in Persian language and literature can be esteemed as a domestic policy to challenge and destabilize what Persian intellectuals conceived to be accounted for cultural backwardness of the preeminent and glorious civilization they once had. This change in literary taste did not occur overnight.

The first reason for Iranian's interest in writing in simple language comes from ideological implications of Rezah Shah's Nationalism and modernization plan. His political agenda was rooted in racist ideology with nationalist provocation as its principal component. This in turn led to the negation of Arabic language and culture as the chief element of cultural backwardness. This opposition against Arabic language was an essential asset in the process of simplification of Persian language purging it of unfamiliar words that were most often unknown to the common people. The association between modernization and simplicity in prose is evidenced in Taqi Rafat's contribution to Kaveh magazine where he asserts his purpose as the promotion of "Western life style" and "struggl[ing] for preservation and purity of Persian language and literature and its [writing system]" (qtd. in Talattof 21). As a result of such attempts, Talattof (2000) asserts, modernist writers finally defeated their traditional counterparts' "worn-out inflated, [and] ornamental style" (23).

Another crucial factor that encouraged simplicity in literary prose comes directly from journalism. Literary journals advocated simple prose which is more available to a greater number of readers, including those who have a rudimentary understanding of language. Talattof (2000) points to a very subtle relation between the simplification of Persian language and modernization: "they [journalists] believed that the process of modernization depended in large part upon simplifying the Persian language and releasing it from the influence of Arab-Islamic culture" (20). It should be noted that journalism itself flourished as a result of the Constitutional Revolution with the promotion of the participation of the public and raising their consciousness as its pivotal objectives. Journals served as the medium for transferring information to all strata of the society, particularly the ordinary people who constituted the driving force of the revolution at the beginning of the twentieth century. 
The ideology of the translator and/or the publishing firm is another factor that contributes to the reception of Ernest Hemingway in Iran. Susan Bassnett (2002) in Translation Studies uses the body metaphor to illustrate the relation between language and culture concluding that:

Language, then is the heart within the body of culture, and it is the interaction between the two that results in the continuation of life-energy. In the same way that the surgeon, operating on the head, cannot neglect the body that surrounds it, so the translator treats the text in isolation from the culture at his peril. (23)

Apparently, she lays emphasis upon the translator's cultural consciousness in singling out a certain text for translation.

Translators in Iran, unlike Western countries, enjoy an unsurpassed phenomenal and prestigious position because "not only is the translator's name printed on the front page of the book, but also he possesses the status of a celebrated intellectual" (Khazaeefarid "Nazariehaye"). In fact, translators are the most prominent agents in selecting elements from the Western tradition which they regard as influential in promoting Persian culture. This is in sharp contrast with Western policies of undermining the status of translators who translate from periphery to dominant culture, which, Lawrence Venuti (2008) protests against in his appreciation of foreignization over domestication (15).

Assuredly, the prestige of translators, in Iran, stems from Iranian audience's zeal, curiosity, and veneration for political, social, cultural, and scientific changes they desperately seek to improve their principal civil concerns. Borrowing Even-Zohar's term from Bassnett's work, Reflections on Translation (2011), Iran exemplifies "a culture in transition" (xi) determined to enrich its culture through agents of change, the most principal of which is, embodied in translating Western ethos. What marks Qajar period as the period of translation in history of Iran (Azarang 217) is that translation in Qajar period was augmented with military needs, and nourished with later modernization program in Pahlavi period. The first impetus for the advancement of translation during Qajar period was the political urgency to modernize the army as Iran was under foreign military attacks and loss of territory was inevitable. The encounters with the Western world during this period immediately influenced the number of translations produced in Iran. Even-Zohar, as elaborated in Bassnett's Reflections on Translation (2011), relates the number of translations with "the stage of development which a culture finds itself; hence, cultures in transitions tend to translate more texts" (xi). Iran, in its early phases of modernism becomes a country with a culture in transition that demonstrates a great hunger for strengthening its cultural heritage through translation in all disciplines. This enthusiasm for translation is accelerated during Qajar period. At this juncture, in Iran, important political events, democratic prospects, and industrial developments took place in the European sphere that had its immediate impact on Iran.

Like the literary sphere, Translation in Qajar period also followed simplification policies. Promotion of translation in Iran owes much to the students who came back to Iran and started translating various texts. The primary impact of these translators upon Persian prose and literature is simplification of language. For, as Abdolhossein Azarang (2015) notes, "immediate translation of scientific texts did not leave any room for compliments, circumlocution and artificiality of language that was accentuated by Arabic unfamiliar language" (253-254). Here, again, as Talattof (2000) contends, "Sadiq Hedayat and M.A. Jamalzadih [among others] believed that cultural backwardness was the main barrier to literary evolution... [They] saw language as the vehicle of culture and dedicated themselves to releasing it from outdated, formulaic styles and artificial rhetoric" (50). It is so far argued that Persian literary taste favoured simplification in language and translation as a result of Constitutional Revolution, advent of journalism, need for communication and promotion of modernism, and purgation of Persian literature of Arabic, unfamiliar, and convoluted words and an attempt to release Iran from the religious tendencies advocated by the pioneers of Modern Persian prose writers who set a model for others to pursue simple language. Under these circumstances, simplicity of style in Hemingway's fiction conformed to the Persian literary taste and is welcomed within the literary circles. Hemingway's literary style, does not challenge the burgeoning Persian modern prose stylistics. Rather, it advocates an unpretentious stance to delve into the most fundamental issues of man's struggle for life, love, and aspirations.

\section{A CHRONOLOGICAL STUDY OF TRANSLATION OF HEMINGWAY BEFORE THE ISLAMIC REVOLUTION}

The first person who introduced Hemingway to Iran was Ebrahim Golestan who translated The Short Happy Life of Francis Macomber in 1949 (Golshiri 296) published by Amir Kabir Publications in Tehran. Amir Kabir, then a private publishing house, was founded by Abdolrahim Jafari in November 1949. Parviz Jahed (2015) in a chapter of the book Neveshtan ba Doorbin (Writing with Camera) titled as "Ebrahim Golestan and his works," refers to A'bedini's opinion on Golestan, in which he is credited as the pioneer in introducing Faulkner and Hemingway through translations to Iranian audience, with notable achievements in imitating Faulknerian style in some of his short story collections (as cited in Jahed 19). Amir Kabir publications soon turned into the largest publishing house in the Middle East. But, then, it did not enjoy a conspicuous status to promote the sale of the book. As Mehdi Mozafari (2010) notes, Daryabandari asserts that according to Amir Kabir's publisher, Abdolrahim Najafi, Ebrahim Golestan's translation of The Short Happy Life of Francis Macomber, did not sell as expected and the "translations were stored in the warehouse" (236).

It is not an overstatement to assert that Golestan's interest in translating Hemingway partly stems from his enthusiasm in Sa'di's style of writing and ideology. The reforming attitude he obtains in his membership of Tudeh party and his interest in simplicity of style are echoes of Sa'di's flirtations with style and subject matter. The emphasis on justice, equality, the governor's responsibility and service to men (Anvari 505-506) has equal correspondence to Golestan's communis- 
tic tendencies. The simplicity of style in Sa'di, as different as it is from Hemingway's literary innovation, shares one thing in common with his prose style: they are both impossible to imitate. Whereas Sa'di's Golestan adorns this simplicity and natural flow with internal and external rhyming, Hemingway deploys realistic narration while distancing from emotional excess. Ebrahim Golestan refers to this feature as untranslatability for Hemingway's unique style.

This interest in Sa'di's style and subject matter that invigorates Golestan's introduction of Hemingway in Iran is reiterated in his interview with Parviz Jahed:

It would be a fallacy to assert that this work is originated from that source. When I was a child, I have read some stories, had some experiences, and saw some people who came to visit my father. I have heard them talking to him... but, there are things that are originated from within. For example, the odour of the bedchamber of the mosque, is something that I have experienced before I read Hemingway or any other writer. These are my personal experiences. If you linger over Hemingway, you are kind of narrow-minded. When it comes to prose, Hemingway's style can never arrive at Sa'di's eloquence in his Boostan. When you have read Boostan, ten times before you read Hemingway, you would be a little influenced. (Jahed 20)

As reluctant as Golestan is in acknowledging Hemingway's influence in his writing, he, nevertheless, uncovers one major source for reception of Hemingway in Iran, i.e. the correspondence and similarity between Hemingway's simplicity of style and the reiterated unpretentious style embedded in the Persian literary heritage. Interestingly, Golestan, was born in Shiraz, the same city where Sa'di, the celebrated Shirazi poet, came from.

In 1949, Ebrahim Dilmaghanian also published The Short Happy Life of Francis Macomber by Amir Kabir publishing firm (Kenarsari \& Afshar 902). Although two translators published this book by the same firm, as Golshiri and Ale-Ahmad contend, Ebrahim Golestan's translation was superior (Abdolahian 67). There was nearly a gap of three decades between the publication of Hemingway' works in America and his entrance into Iran. The reason for this lapse, obviously is that Iran was then nourished by European and especially Russian and French literature. Then, if Iran was under the influence of the European sphere why she suddenly turned to an American writer and what aborted this early reception? In response to these questions, the motivation of the translators to single out these works should be taken into account. Translation of Ernest Hemingway was instigated with the interest of Marxist-oriented translators in Hemingway. Ebrahim Golestan was a member of Tudeh Party (The Iranian Communist Party) a political institution that was inaugurated in 1941 "immediately after the abdication of Reza Shah" (Abrahamian 281) that had "eliminat[ion] of dictatorship, safeguard[ing] the rights of ... the masses" and "participat[ing] in the world wide struggle of democracy against barbarism and fascism" in its agenda (Abrahamian 282). Hemingway is not a subject of interest until Mardom (The People), the official daily newspaper of Tudeh party, publishes Goletstan's full-fledged introduction of Hemingway and translations of two short stories (Mozafari 234-236). This incident is also reiterated by Daryabandari who later precipitated Hemingway's fame into Iran. As Hariri's book of published interview with Daryabandari reveals, Daryabandari's first acquaintance with Hemingway goes back to Golestan's extensive biography of Hemingway and translations: "I" first read about Hemingway in Mardom in 1945" (43). This newspaper published the biography and contribution of Marxist Russian authors and the likeminded writers around the world to promote anti-fascism. The Publication of Golestan's introduction to Hemingway as well as the translation of his short stories are in line with ideological scopes of the party. For Ernest Hemingway's anti-fascist tendencies is evident in his speech to the American writers' congress in 1937 in New York: "There is only one form of government that cannot produce good writers, and that system is fascism. For fascism is a lie told by bullies. A writer who will not lie cannot live or work under fascism" (Bruccoli 193). Watson refers to Hemingway's personal involvement in war "as a propagandist, polemicist, public spokesman and fund raise" (Kerstin 136). Meyers also refers to Hemingway's attempt to raise money for funding "ambulances in Spain" and "the Republican side" as well as "taking part in producing a film about a war that was shown in the U.S." (Kerstin 136). In Iran, Daryabandari's review in 1961 also features Hemingway's anti-Fascist tendency (Daryabandari 400).

These ideological intentions of Ernest Hemingway mobilized his entrance into Iran. It is noteworthy to say that Hemingway first emerged in Mardom newspaper in 1945, a decade before the author won the Noble Prize (1954) and Pulitzer Prize for Fiction (1953) and his ensuing extensive international recognition and fame. Due to the prior anonymity of Hemingway in Iran, it is not unlikely to claim that the translations or introductions that Golestan provided served their ideological purposes. He incorporated Hemingway's translation, in André Lefevere's term, as a "rewriting" (vii) of its original context, a strategy to manipulate a literary work, a carrier of a certain ideology, with the power to install a new culture on the prevailing ethos. In this respect, the first translators of Hemingway in Iran function as ideological and cultural rewriters for they embrace Hemingway's translation in accordance with anti-fascist concerns that call for political and social change.

After Golestan, A. Karen in 1950 translated The Sun Also Rises via Sepehr Publication. The Old Man and the Sea became translated by Yahyavi in 1952, the same year in which this novella was published in America. It should be noted that the widespread practice of translation of Hemingway's fiction did not occur until the author won Pulitzer and Noble Prize in 1953 and 1954, respectively. In 1953, Parviz Daryoosh translated Across the River and into the Trees which was reprinted in 1954, 1961, 1967, and 1973. He also translated To Have and Have not in 1954. In the same year, A Farewell to Arms was translated by Najaf Daryabandari in Safi Ali Shah publications. This translation of $A$ Farewell to Arms, though not the apotheosis of his career, signals Marxist agenda. His main interest in translating Hemingway is fostered by Ebrahim Golestan who later provided him with A Farewell to Arms. Hemingway's advocacy of the Left, his personal involvement in war against Fascism as well as 
a direct reproduction of these elements in the novel, echo the same ideology for the translator. After publishing this book, the translator, Daryabandari, and Morteza Keyhan, as the person responsible for its publication, were immediately arrested. Keyhan's execution, Daryabandari's immediate arrest and imprisonment, preponderated the book's recognition and fame. Golestan underestimates Daryabandari's political activity and his consequent arrest for the translation of Hemingway's A Farewell to Arms as a proof of his Marxist tendencies. For him, as Jahed refers, "translation of a book is not a strong proof to call a person an active political figure of Tudeh party" (138). But, Daryabandari's arrest in 1954 is not accidental. Being a member of a dissident organization, Daryabandari refers to his brief acquaintance with Morteza Keyhan, the intermediary and an active member of the party (Mozafari 63) who published the translation in a private publishing house called Safi Ali Shah. There is no doubt that Daryabandari consciously manipulates literature to introduce new perspectives so as to challenge the ruling power. His arrest in 1954 (Mozafari 59) was the government's natural reaction to what André Lefevere (1992) terms as "literature's shaping power of one culture upon another" (vii). It should be noted that Golestan's review on Hemingway in Tudeh's official newspaper enjoys the same subversive potential. As such, Daryabandari's interest in translating Hemingway is instigated more on the basis of ideological grounds than his attention to Hemingway's stylistic prowess.

Shojaedin Shafa in 1955 translated Hemingway's short story titled as "The End of Something" was included in a collection of short stories in Shiraz Wine and Ten More Stories. The translation of Men without Women occurred in 1956 by M. Abbasi. Snows of Kilimanjaro was published by Amir Kabir publications with Ali Mohit as the translator. Another fortunate instigator for the added fame of Hemingway in Iran was, ironically enough, the death of the writer that propelled an array of translators who either translated the already printed works or introduced new works via translating them. The Sun Also Rises was translated in 1961 by Moghadam in Jibi Publications. In 1966, The Old Man and the Sea was translated by Ali Salimi via Sekkeh publishing firm. Another attempt to retranslate A Farewell to Arms is made by Saeidi in 1969 via Shahriar publications. Nazi Azima also translated this novella in 1975 by Amir Kabir Publications. A Farewell to Arms was once more translated in 1970 by Marashi via Jibi Publications. Javad Shams in 1973 published a translation of Snows of Kilimanjaro through Pejwak Publications. The first translation of The Undefeated and Ten other Short Stories came out in 1963 by Sirous Tahbaaz. Islands in the Stream was translated in 1971 by Naser Khodayar in Donyaye Ketab publications.

When Iranian translations of Hemingway's oeuvres are compared with the timeline of Ernest Hemingway's publication in America, it is understood that Hemingway's entrance in Iran took place nearly three decades after the publication of Hemingway's first work Three Stories and Ten Poems (1923) which marked him as an early success. Although, Hemingway's first serious achievement that brought him into spotlight across the continents was The Sun Also Rises (1926) followed by In our Time (1925), another successful work, Karen's translation of the novel in 1950 did not find the public attention in Iran. Instead, Across the River and into the Trees, that was reviewed as the poorest work of fiction written by Hemingway is reprinted after Hemingway's death in Iran. Lack of judicial review in Iranian literary journals is, in part, responsible for this hectic trend. Sokhan literary journal only refers briefly to Hemingway's fortunate escape from death or his Noble prize in the international literary news column. The first serious and influential review of Hemingway is published after the death of Hemingway in 1961 in Sokhan literary journal by Daryababdari. Najaf Daryabandari, who later becomes the most celebrated translator of Hemingway, writes an article titled as "Ernest Hemingway, Mardi ke Mord [The Man Who Died]" in which he brilliantly elucidates Hemingway's achievements. Daryabandari speaks in a familiar tone to the Iranian audience in simple language and plain tone: "Hemingway discarded the bunch of supreme attributes, lamentations and complaints employed by the so-called Sentimental writers, as garbage" (396). Daryabandari, brilliantly, illuminates Hemingway's stylistic features and choice of subject matter that distinguished him as a revolutionary writer (396). This review instigates a vast array of translations and reprints after the death of the writer. Another possible contribution to the fame of Ernest Hemingway is his uncanny death elaborated in Sokhan magazine by Daryabandari:

An Early Monday morning, $2^{\text {nd }}$ of July, Hemingway woke up. He looked fine. He came downstairs and took up his expensive shotgun. Nobody knew what happened. Gun fire was heard. When his wife rushed to him, he was already gone. Lips, chin, and a part of his cheekbone remained. The rest part of his head was scattered. His wife believed it was an accident. But this accident should have been a rare case since it was evident that the gun was shot in the mouth. ("Ernest Hemingway, Mardi ke Mord" 402)

The Iranian audience's interest in Hemingway's works after his suicide was not accidental. Sadeq Hedayat (one of the pioneers of Modern Persian prose literature who also favoured simple style) had already committed suicide in France in 1951, less than a decade before Hemingway's death. After his suicide, his fame doubled in Iran. Moreover, two years after Hedayat's suicide, his fame was escalated via André Breton who wrote an article titled as, "Des Capucines violettes," in the magazine Médium on June 1953 hailing Hedayat as a true surrealist writer (Beard 247). There is no doubt that the intellectuals and the Iranian readership who adored Hedayat's gloomy masterpieces such as his Blind $O w l$ became stirred by the suicide of another genius and started to discover Hemingway as another genius with an early death and struggled to unearth his state of mind via reading his translated fiction.

For Whom the Bell Tolls was translated three times. Rahim Namvar, Ali Salimi, and Reza Marashi's translations are received with great enthusiasm during the last two decades before the Islamic Revolution. People's political dissatisfaction, the call for a change, and the restrictions felt under dictatorship were some of the solid agents contributing to this reception. One of the translators, Rahim Namvar, was himself an active member of Tudeh party. A Farewell to Arms 
was another work which suddenly became popular after the death of Hemingway. The translator's introduction before the text which was first printed in Sokhan literary journal, Daryabandari's "Ernest Hemingway, the Man who Died," counts for the popularity of the novel. Indeed, Daryabandari's translation was reprinted seven times during this period. His simplicity of style and fluency of words also appealed to a large audience. It should be noted that Daryabandari owes his publicity, fame, and durability to the simple style of writing he opts. He admires Mohammad Ghazi’s translation of Don Quixote as an artistic creation (Hariri 29). What Daryabandari appreciates in Ghazi holds true for his own style. Mohammad Ghazi serves as his role model in the artistic creation of a language, which as fresh as it looks, nevertheless, sounds familiar for the reader. The fact that Daryabandari discards later works of Golestan, as well as Indian style in Persian verse (also called Isfahani or Safavi style that became prevalent in the fifteen century till mid- $18^{\text {th }}$ century in Iran) is that he favours simplicity. In the interview Mozafari published, Daryabandari disapproves of Indian style on the basis that "it retains ornate style and artificiality" (248). In another published interview that Hariri (1998) provided, Daryabandari refers to Hedayat and Chubak as the first influences upon him after Ali Dashti (53). Daryabandari appreciates Hemingway's unique style of writing which he believes is mostly seen in his short stories (Mozafari 235). He refers to Hemingway's fluctuation in style as degenerate (Mozafari 235). Thus, Daryabandari, under the influence of Hedayat and Chubak, adopts simplicity of style. Simple style is the unique feature in Hemingway's stylistic strategy that resonates the same domestic trend in Persian literature. Golestan also reluctantly admits Daryabandari's achievement in translation of Hemingway. Golestan fails to relate terseness in Persian literature as a result of modern prose movement in literature. He repudiates Daryabandari's expertise in translation of Hemingway insinuating that famous translators like Daryabandari out-Hemingway Hemingway. In his published interview with Jahed, Golestan contends that:

Hemingway is more noted for his prose. Though, his prose fluctuates. He has dedicated himself to his prose. That is why his text is untranslatable. You cannot imitate this in other languages. His French translations are entirely different from his style of writing. Perhaps, in some Persian translations, his prose is well imitated [my emphasis]. But, it is because of the terseness and insufficiency [of words] of Persian language. Still, the same rhythm is never transferred into the second language. Perhaps, the recreation would be much better [my emphasis], but it is never the same. (Jahed 112)

Across the River and into the Tress is the next book which is reprinted after the death of Ernest Hemingway. In the next decade, there is a significant rise in the number of reprints of this particular work. In America, this work was reviewed as one of the least successful work of Hemingway. Besides the suicidal attempt of the author that gave rise to the popularity of his books in Iran, the preface the translator, Parviz Daryoosh, wrote before this translation led to its widespread appeal. In this preface, Daryoosh questions the negative response of the American reviewers asserting that there are parallels between the protagonist of this work and that of
The Old Man and the Sea. The Snows of Kilimanjaro is the next popular work. The Death and love motif (either for life or for a person) reiterated in most of the works echo the same themes among native writers in Iran.

The anti-Fascist tendencies, reverberated in most of these popular works, political disturbances, the quality of translations, and the translator's preface to the book influenced people's taste. It is interesting to note that a novel like The Sun Also Rises that depicts the American's frustrated youth's struggle to take recourse to oblivion through Alcohol and Sexual encounters does not appeal to Iranian audience. This decline in interest is perceptively evident in the last decade before the Revolution since the politically conscious audience during those critical years looked for a source of inspiration to bring about change. As such, the audience less tended towards inertia and oblivion than subjects that boosted their courage and awareness. In the same manner, The Short Happy Life of Francis Macomber, as the first translated work of Hemingway in Iran was not well-received by Iranian readership. This lack of interest is justified by the ideological detachment of the Marxist elites from the middleclass readers. For it took some time for the Iranian audience to receive the revolutionary message that was conveyed via these translations. Hemingway's translation proliferates in Iran after the author wins the most ambitious literary awards. However, the public reception of Hemingway is delayed until his death that added to his publicity and fame.

\section{CONCLUSION}

Iran, at the beginning of the twentieth century, promoted a policy of simplification and purgation of Persian literature and language from Arabic words. Initiated as a by-product of the modernization program after the Constitutional Revolution, purgation of Persian literature from the entanglements of traditional literature and Arabic influence was advocated by pioneers of modern Persian literary prose such as Sadeq Hedayat and Mohammad Ali Jamalzadeh. This policy of simplification, is in line with Hemingway's unpretentious, terse, and simple style that, in turn, precipitates Hemingway's literary fortune in Iran. In other words, Hemingway's literary reception does not challenge the literary taste of Iranians. Rather, his stylistic features confirm the novelty of modern Persian prose writers. However, Hemingway's entrance into Iran was not a disinterested literary transaction. Besides the policy of simplification, ideological and political concerns also prompted the entrance of Hemingway in Iran. In other words, Ernest Hemingway's literary fortune owes much to the ideology of translators such as Ebrahim Golestan, Rahim Namvar, and Najaf Daryabandari, who translated Hemingway more for Hemingway's leftist tendencies than his literary and stylistic prowess. Indeed, the first reviews and translations of Hemingway in Iran appears in Mardom, an official magazine of Tudeh party. It is not an overstatement to argue that Hemingway's initial entrance into Iran functioned as a vent for presenting communist ideology through the literary production. Although Hemingway's fame doubled after he won the noble prize but it is not until his death that Iranian readers demonstrate a great interest in 
Hemingway. Najaf Daryabandari's article in Sokhan refers to Hemingway's death as an act of suicide. Iranian readers, then, demonstrate a great interest in uncovering the mindset of Hemingway.

\section{REFERENCES}

Abdolahian, H. (2003). Tarihkcheye Tarjomeye Asar-e Hemingway dar Adabiat-e Farsi [A Chronology of Hemingway Translations in Persian Literature]. Mashhad Faculty of Literature, 2(141), 65-73.

Abrahamian, E. (1982). Iran Between Two Revolutions. Princeton: Princeton University Press.

Anushiravani, A. (2015). Nesbate Mian-e Tarjome va Adabiat-e Tatbighi [The Relation between Translation and Comparative Literature]. Motarjem, 51-60.

Anvari, H. (2014). Negahi be Golestane Sadi [A look at Sa'di's Golestan]. In H. Anvari, Inguneh Mandegar [This Much Lasting] (pp. 503-512). Tehran: Islamic Studies Institute.

Azarang, A. (2015). Tarikhe Tarjome dar Iran [The History of Translation in Iran]. Tehran: Ghoghnous.

Bassnett, S. (2002). Translation Studies ( $3^{\text {rd }}$ ed.). London: Routledge.

Bassnett, S. (2011). "Introduction" in Reflections on Translation (pp. ix-Xvi). Bristol: Multilingual Matters.

Beard, M. (1990). Hedayat's Blind Owl as a Western Novel. Princeton: Princeton University.

Bruccoli, M. J. (Ed.). (1986). Conversation with Ernest Hemingway. Jackson \& London: University Press of Mississippi.

Daryabandari, N. (1961, August). Ernest Hemingway, Mardi ke Mord [Ernest Hemingway, the Man who Died]. Sokhan, pp. 396-402.

Frederking, L. c. (Ed.). (2010). Hemingway on Politics and Rebellion. New York: Routledge.

Golshiri, H. (1999). Baq dar Baq [Garden in Garden]. Tehran: Niloofar.
Hariri, N. (1998). Yek Goftego: Ba Najaf-e Daryabandari [A Conversation with Najaf Daryabandari]. Tehran: Karnameh.

Holub, R. C. (1984). Reception Theory: A Critical Introduction. London: Methuen.

Jahed, P. (2015). Neveshtan ba Durbin: Ru dar Ru ba Ebrahim-e Golestan [Writing with the Camera: Face to Face with Ebrahim Golestan]. Tehran: Akhtaran.

Jost, F. (1975). Introduction to Comparative Literature. Indianapolis: Pegasus Publications.

Kenarsari, F., \& Afshar, M. (1998). Ketabshenasi-e Roman va Majmuehaye Dastani-e Motarjem [Bibliography of the Translator's Novels and Story Collections]. Tehran: Institution of Publications and Distribution of the Minisrtry of Culture and Islamic Guidance.

Kerstin, H. (2010). Hemingway's For Whom the Bell Tolls: Rebellion and the Meaning of Politics in the Spanish Civil War. In L. C. Frederking (Ed.), Hemingway on Politics and Rebellion (pp. 133-150). New York: Routledge.

Khazaeefarid, A. (2016, January 26). Nazariehhaye Adabi dar Iran [Literary Theories in Iran]. The First Conference on Translation Studies. Shiraz University. Shiraz.

Lefevere, A. (1992). Translations, Rewriting, and the Manipulation of Literary Fame. London: Routledge.

Mirsadeghi, J. (1991). Adabiat-e Dastani [Literary Fiction]. Tehran: Mahoor.

Mozafari, M. (2010). Yek Goftegu ba Najaf-e Daryabandari [Connversation with Najaf Daryabandari]. Tehran: Morvarid.

Prawer, S. S. (1973). Comparative Literary Studies: An Introduction. London: Gerald Duckworth \& Co. Ltd.

Talattof, K. (2000). The Politics of Writing in Iran: A History of Modern Persian Literature. Syracuse: Syracuse University Press.

Venuti, L. (2008). The Translator's Invisibility: A History of Translation (second ed.). London: Routledge. 